\title{
Milligram per Minute
}

National Cancer Institute

\section{Source}

National Cancer Institute. Milligram per Minute. NCI Thesaurus. Code C73742.

A dose calculation expressed in milligram(s) period of time equal to sixty seconds. 